\section{Growth Responses of Hydroponically Grown Sweetpotato Tolerant and Intolerant of a Continuous Daily Light Period}

\author{
D.G. Mortley ${ }^{1}$, P.A. Loretan ${ }^{2}$, W.A. Hill ${ }^{2}$, C.K. Bonsi ${ }^{2}$, and C.E. Morris ${ }^{2}$ \\ George Washington Carver Agricultural Experiment Station, Tuskegee \\ University, Tuskegee, AL 36088
}

Additional index words. Ipomoea batatas, nutrient film technique, harvest index, photoperiod, photosynthetic photon flux

\begin{abstract}
Two sweetpotato [Ipomoea batatas (L.) Lam] genotypes ('Georgia Jet' and the breeding clone TI-155) were grown at 12-, 15-, 18-, and 21-h light/12-, 9-, 6-, 3-h dark cycles, respectively, to evaluate their growth and elemental concentration responses to duration and amount of daily lighting. Vine cuttings $(15 \mathrm{~cm}$ long) of both genotypes were grown in rectangular nutrient film technique channels for 120 days. Conditions were as follows: photosynthetic photon flux (PPF) mean $427 \mu \mathrm{mol}^{\circ} \mathrm{m}^{-2} \bullet \mathrm{s}^{-1}, 28 \mathrm{C}$ day $/ 22 \mathrm{C}$ night air cycle, and $70 \% \pm 5 \%$ relative humidity. The nutrient solution used was a modified half-strength Hoagland's solution. Storage root count per plant and per unit area, yield (in grams per square meters per day), and harvest index increased, while production efficiency (in grams per mole) decreased with increased daily PPF. Stomatal conductance for both genotypes declined with increased daily PPF. Leaves were smallest for both genotypes at the 21-h light period, while storage root yield declined as leaf area index increased. Except for a linear decrease in leaf $\mathrm{N}$ and $\mathrm{K}$ with increased light period, elemental concentration was not significantly influenced.
\end{abstract}

Research on growth responses of food crops under controlled environment conditions is being conducted by the National Aeronautics and Space Administration (NASA) through its Controlled Ecological Life Support Systems (CELSS) program for long-duration space missions. In ongoing studies (Hill et al., 1989; Mortley etal., 1991a, 1991b, 1993) at Tuskegee Univ.'s NASA Center for Food Production, Processing, and Waste Management, we are evaluating hydroponic sweetpotato production using a nutrient film technique (NFT). In NFT, plant roots are exposed to a thin film of recirculating nutrient solution within a growth trough or channel (Cooper, 1974a, 1974b; Loretan et al., 1989; Hill et al., 1989; Morris et al., 1989).

Duration of light is among the critical environmental factors known to influence growth and yield of sweetpotato (Bouwkamp, 1985). In early studies, Kim (1957) observed a stimulation in storage root formation under long days and suggested that this effect resulted from greater net $\mathrm{C}$ fixation rather than being an

Received for publication 12 May 1995. Accepted for publication 12 Dec. 1995. Contribution no. 261 of the George Washington Carver Agriculture Expt. Station, Tuskegee Univ. This research was supported by funds from the U.S. National Aeronautics and Space Administration (grant no. NAGW-2940) and U.S. Dept. of Agriculture/Controlled Ecological Life Support Systems (grant no. ALX-SP-1). The use of trade names in this publication does not imply endorsement by the George Washington Carver Agricultural Expt. Station. The cost of publishing this paper was defrayed in part by the payment of page charges. Under postal regulations, this paper therefore must be hereby marked advertisement solely to indicate this fact.

${ }^{1}$ Research Assistant Professor.

${ }^{2}$ Professor. effect of photoperiod. McDavid and Alamu (1980) reported a higher storage root yield for plants grown under $\approx 12$-h light periods than for plants grown under shorter $(8 \mathrm{~h})$ or longer (18 h) light periods; similarly, Porter (1979) produced higher yields with 14 -h light periods than with 8-h light periods.

In growth chamber studies using potted plants, the number of storage roots per plant, total yield, and fibrous root dry weights of three sweetpotato cultivars grown in continuous light ( $24 \mathrm{~h}$ ) were higher than at a 12-h light period, with both receiving approximately equal instantaneous photosynthetic photon flux (PPF). However, the continuous light plants received twice as much total PPF each day (Bonsi et al., 1992), and we concluded that continuous light did not inhibit successful storage root initiation and enlargement. In our controlled environment studies, 'Georgia Jet' technique in response to daily light period. and 'Georgia 120' grew and produced storage roots under 12-h light periods or in continuous light (Bonsi et al., 1992, 1993). However, TI155 , a breeding clone that has shown the highest yields to date in NFT under 12-h lighting, has not produced storage roots under continuous light, probably because photosynthates were favoring foliage over storage root development (D.G.M., unpublished data; Tibbitts and Cao, 1994). Typically, the plants grown in NFT under continuous light exhibited light-induced injury characterized by chlorotic and necrotic spotting on expanding leaves, stunted growth, and little foliage production. This result suggests that TI- 155 may be intolerant of continuous light in NFT and that the optimum light period is $<24 \mathrm{~h}$.

Our objective was to compare yield and physiological growth responses of two sweetpotato genotypes, one tolerant and one intolerant of continuous lighting, grown at four light periods between 12 and $21 \mathrm{~h}$ using NFT.

\section{Materials and Methods}

Four 15-cm-long vine cuttings each of TI155 and 'Georgia Jet' (intolerant and tolerant of continuous light, respectively) were grown in $0.15 \times 0.15 \times 1.2-\mathrm{m}$ NFT channels (Morris et al., 1989; Mortley et al., 1991a) in controlled environment, reach-in growth chambers (Percival, Boone, Iowa). Plants were subjected to daily light periods of $12,15,18$, or 21 $\mathrm{h}$, which provided $\approx 18,23,28$, and 32 $\mathrm{mol} \cdot \mathrm{m}^{-2} \cdot \mathrm{d}^{-1}$ of PPF, respectively. PPF at the top of the canopy $(20 \mathrm{~cm}$ below the lamps) was $427 \pm 23 \mu \mathrm{mol} \cdot \mathrm{m}^{-2} \cdot \mathrm{s}^{-1}$. The PPF was supplied by a 2 cool-white fluorescent : 1 incandescent lamp mixture and was measured weekly with a quantum sensor (LI-COR, Lincoln, Neb.). The temperature was maintained at $28 \mathrm{C}$ in the light and $22 \mathrm{C}$ during the dark period, and the relative humidity was $70 \% \pm 5 \%$.

A modified half-Hoagland nutrient solution (Hoagland and Arnon, 1950) with a $1 \mathrm{~N}$ : $2.4 \mathrm{~K}$ ratio was used. Each rectangular growth channel contained four plants spaced $25 \mathrm{~cm}$ apart, and channels were positioned $25 \mathrm{~cm}$ apart. The channels were inclined with a $1 \%$ slope. Each channel was supplied by a 30-liter reservoir. The nutrient solution $\mathrm{pH}$ was main-

Table 1. Plant characteristics of 'Georgia Jet' (GJ) and TI-155 sweetpotatoes grown in nutrient film

\begin{tabular}{|c|c|c|c|c|c|c|}
\hline \multirow{2}{*}{$\begin{array}{l}\text { Light } \\
\text { period } \\
\text { (h) }\end{array}$} & \multirow[b]{2}{*}{ Genotype } & \multicolumn{3}{|c|}{ Storage root } & \multicolumn{2}{|c|}{ Leaves } \\
\hline & & No./plant & No. $/ \mathrm{m}^{2}$ & $\begin{array}{c}\text { Dry matter } \\
(\%)\end{array}$ & $\begin{array}{c}\text { Area/leaf } \\
\left(\mathrm{cm}^{2}\right)\end{array}$ & No./plant \\
\hline \multirow[t]{2}{*}{12} & GJ & 2.4 & 9.6 & 14.5 & 50.8 & 172 \\
\hline & TI-155 & 4.0 & 16.0 & 16.6 & 37.6 & 184 \\
\hline \multirow[t]{2}{*}{15} & GJ & 3.7 & 14.8 & 16.1 & 54.0 & 127 \\
\hline & TI-155 & 3.5 & 14.0 & 15.8 & 37.3 & 178 \\
\hline \multirow[t]{2}{*}{18} & GJ & 3.1 & 12.4 & 15.9 & 50.0 & 134 \\
\hline & TI-155 & 5.4 & 21.6 & 16.5 & 35.9 & 177 \\
\hline \multirow[t]{2}{*}{21} & GJ & 5.1 & 20.4 & 15.3 & 47.7 & 122 \\
\hline & TI-155 & 8.2 & 32.8 & 16.1 & 28.7 & 229 \\
\hline Cuiltivar & & ** & ** & $* *$ & $* * *$ & $* * *$ \\
\hline Light period & & $* * *$ & $* * *$ & NS & ** & NS \\
\hline Cuiltivar $\times$ light & & & & & & \\
\hline period & & NS & NS & NS & NS & NS \\
\hline Linear & & $*$ & $*$ & NS & NS & NS \\
\hline Quadratic & & NS & NS & NS & NS & NS \\
\hline
\end{tabular}

HortScience, Vol. 31(2), ApriL 1996 
tained between 5.5 and 6.0 by manually adding either dilute $\mathrm{NaOH}$ or $\mathrm{HCl}$. Solution temperature (24 to $28 \mathrm{C}$ ) and electrical conductivity (100 to $120 \mathrm{~S} \cdot \mathrm{m}^{-1}$ ) were monitored, and solutions were changed every 2 weeks. The solution was continuously pumped from each reservoir to the high end of each growth trough by small magnetic drive pumps (Little Giant model 2P037; Tecumseh Products Co., Oklahoma City, Okla.). A 1-liter. $\mathrm{min}^{-1}$ flow rate was set by using an inlet valve.

Each vine cutting was held in place by a flat plate assembly (Morris et al., 1989) attached to the sides of the channels by a flexible white and black vinyl covering. Vines were trained as they grew by tying them to vertical strings suspended $\approx 1 \mathrm{~m}$ above each growing channel.

Beginning 28 days after planting (DAP), stomatal conductance was measured at the middle of each light period with a steady-state porometer (model LI-1600; LI-COR). The measurements were taken on the fourth fully expanded leaf at the terminals of the vines from each plant at the top of the canopy. These measurements were continued each week for the 120-day duration of the study.

Leaf samples, consisting of the most recently expanded leaf from the terminals of the vines, were collected from each plant at 63 DAP. Leaf samples were dried at $70 \mathrm{C}$ for $48 \mathrm{~h}$ and analyzed for $\mathrm{N}, \mathrm{P}, \mathrm{K}, \mathrm{Ca}, \mathrm{Mg}, \mathrm{Mn}, \mathrm{Fe}, \mathrm{B}$, $\mathrm{Cu}$, and $\mathrm{Zn}$ by the Plant and Soil Testing Laboratory at Auburn Univ. (Hue and Evans, 1986).

Plant storage roots and all foliage were harvested 120 DAP. Plants were cut at the base, all leaves were removed, and total leaf area was determined with an area meter (model 3100; LI-COR). Leaves and vines were weighed fresh and after drying for $72 \mathrm{~h}$ at $70 \mathrm{C}$. Storage root fresh weights were determined, and a 25-g sample of each root from each plant was dried at $70 \mathrm{C}$ for $72 \mathrm{~h}$. This information was used to calculate a fresh-to-dry weight conversion factor to estimate storage root dry weight. Harvest index (HI) (root dry weight $\div$ total plant dry weight $\times 100$ ) was determined. The experiment was repeated, and all data were subjected to linear regression analysis by the general linear models procedure (SAS, 1985).

\section{Results and Discussion}

There was a significant genotype and light period main effect for number of storage roots produced per plant (Table 1). This effect was manifested as a near linear increase in the number of storage roots for both genotypes as the light period increased. No genotype $\times$ light period interaction was evident. The general increase in the number of storage roots per plant in response to light period was similar to the increase reported by Bonsi et al. (1992) for sweetpotatoes exposed to continuous light. The fact that storage root dry-matter yield per plant was similar for plants (particularly TI155) at the 18-and 21-h light periods, although storage root count was higher at the 21 -h light period, indicates that individual storage roots were larger at the shorter light period.
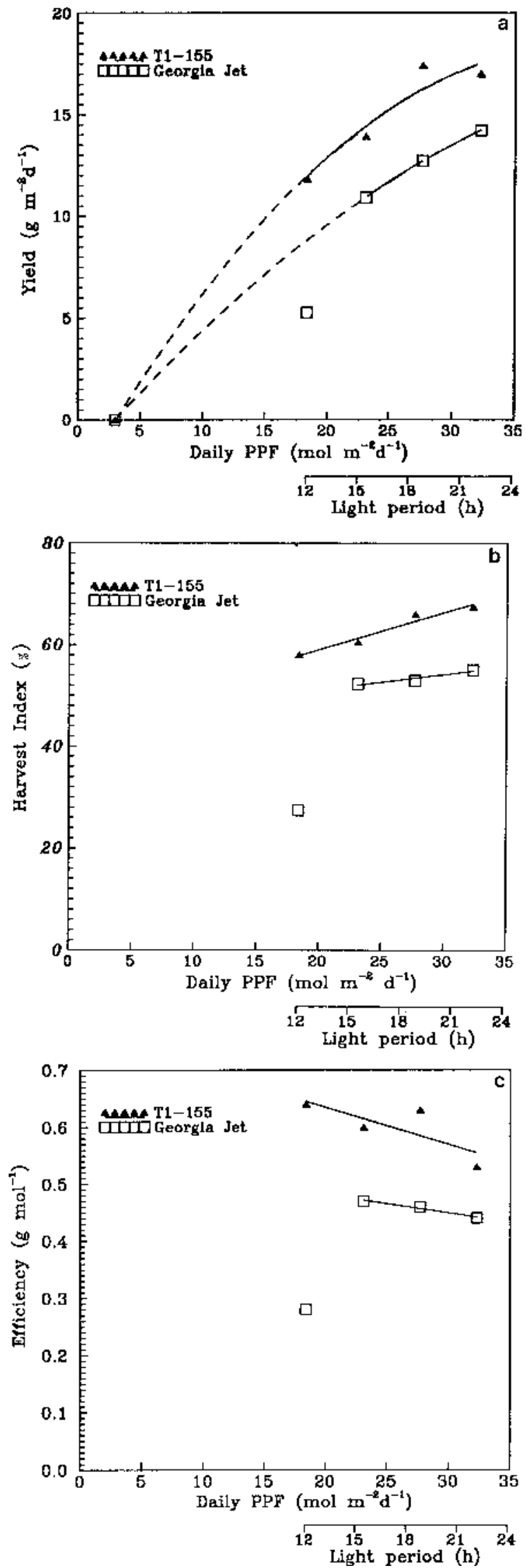

Fig. 1. (a) Storage root yield of TI-155 and 'Georgia Jet' sweetpotatoes in response to daily photosynthetic photon flux (PPF). The datum point at $\approx 3 \mathrm{~mol} \cdot \mathrm{m}^{-2} \cdot \mathrm{d}^{-1}$ represents the light compensation point. (b) Harvest index (root mass $\div$ total plant mass) of TI-155 and 'Georgia Jet' sweetpotatoes in response to daily PPF. (c) Production efficiency for edible yield of TI-155 and 'Georgia Jet' sweetpotatoes in response to daily PPF. 
Percent dry matter (\%DM) of storage roots differed with cultivar $(P<0.03)$, with that of TI-155 exceeding that of 'Georgia Jet' (Table 1). Light period did not significantly influence $\% \mathrm{DM}$ of storage roots for either cultivar.

Increasing light period had no consistent effect on the number of leaves produced per plant (Table 1). Area per leaf was influenced by cultivar and light period (Table 1). 'Georgia Jet' leaves were larger than those of TI155. Other than the slight increase in leaf area for 'Georgia Jet' with $15 \mathrm{~h}$ of light, area per leaf declined steadily for both genotypes as daily PPF increased. TI-155 plants produced significantly more leaves than 'Georgia Jet'. Thus, the number of leaves produced per plant was influenced more by the differences between genotypes than light period. Leaf area and count for TI-155 were similar for the 12and 18-h light periods, but leaf area decreased and leaf count increased at $21 \mathrm{~h}$; thus, although leaf count was higher, individual leaves were smaller.

Yield response curves show that storage root yield for both cultivars increased with increasing daily PPF (Fig. 1a). The yield of 'Georgia Jet' at the 12-h light period was uncharacteristically low, for which we have no logical explanation. However, this low yield is probably an artifact of some unusual occurrence in that particular chamber.

$\mathrm{HI}$, which is an indication of the relative distribution of photosynthates between storage roots in relation to the total plant, was significantly influenced by light period and cultivar (Fig. 1b). HI increased as daily PPF increased. This result suggests that plants of both cultivars were source-limited because increasing the source capacity with higher daily PPF increased $\mathrm{C}$ partitioning to the edible roots. Except for 'Georgia Jet' with $12 \mathrm{~h}$ of light, the HI values are similar to those for field-grown sweetpotatoes (Bhagsari and Ashley, 1990). A primary concern of a CELSS is to maintain a high $\mathrm{HI}$, thereby reducing waste for recycling.

One critical aspect of a CELSS is the conversion of radiation energy into edible yield. The efficiency of this conversion is best expressed as grams of edible biomass per mole of photons. The production efficiency of both cultivars declined as daily PPF increased (Fig. 1c). However, this decline in production efficiency was small $(<10 \%)$. The production efficiency of total biomass for TI-155 was $>1$ $\mathrm{g} \cdot \mathrm{mol}^{-1}$. This extremely high value probably was due to side lighting of plants in the chambers. If the effective area per plant is increased by only $5 \mathrm{~cm}$ on a side (a small amount of side lighting), the effective spacing would be 0.09 $\mathrm{m}^{2} /$ plant. In turn, this lighting would decrease the yield per unit area to a value that could be obtained in a large canopy in which side lighting would be nonexistent.

Both genotypes showed symptoms of light injury (chlorotic leaves, slow growth) early in the growth cycle for the two longest light periods (18 and $21 \mathrm{~h}$ ), but they seemed to recover by 42 DAP, especially 'Georgia Jet'. Although not measured in this study, leaf carbohydrates may have increased to injurious

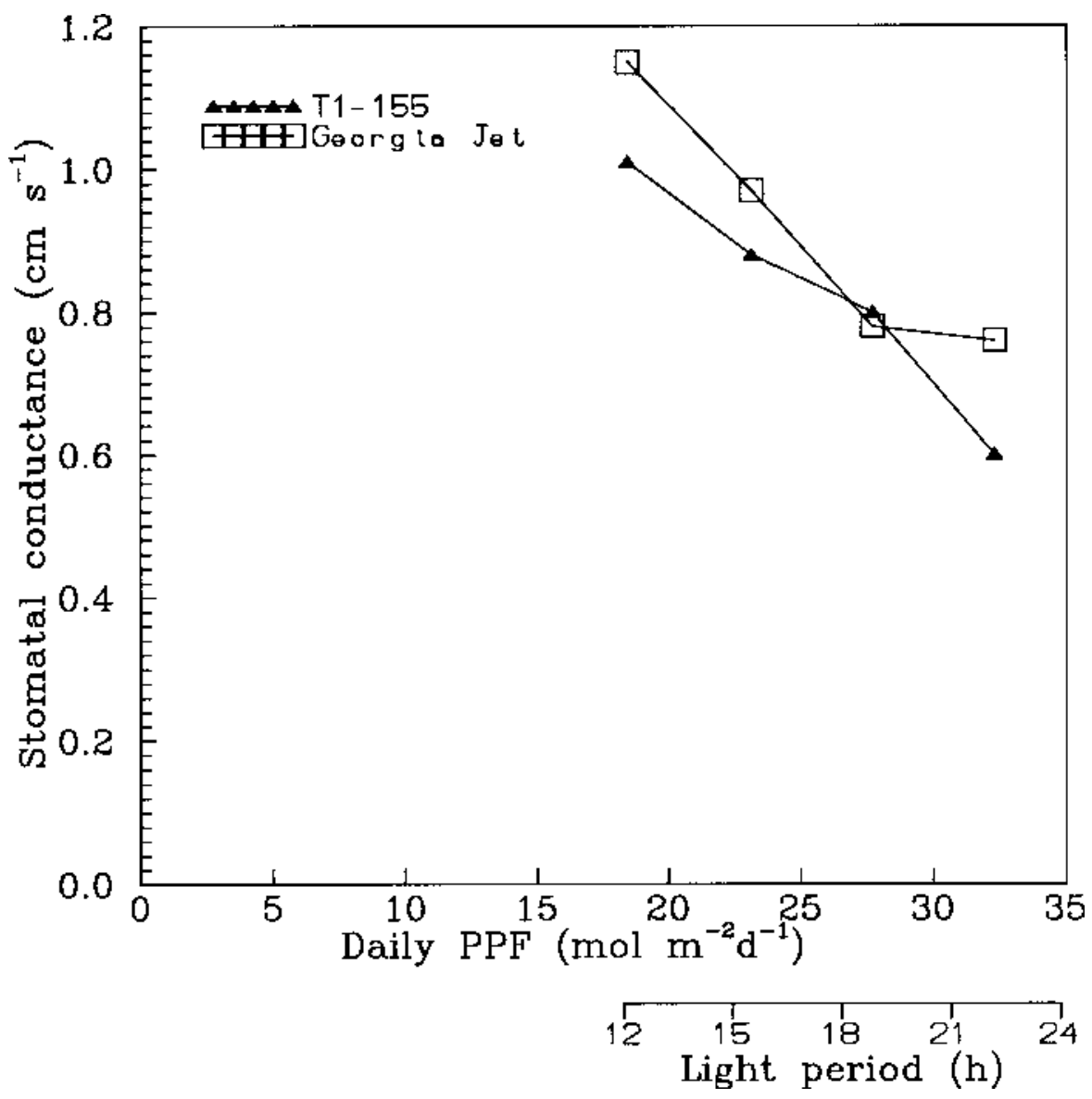

Fig. 2. Stomatal conductance of TI-155 and 'Georgia Jet' sweetpotatoes in response to daily photosynthetic photon flux (PPF).

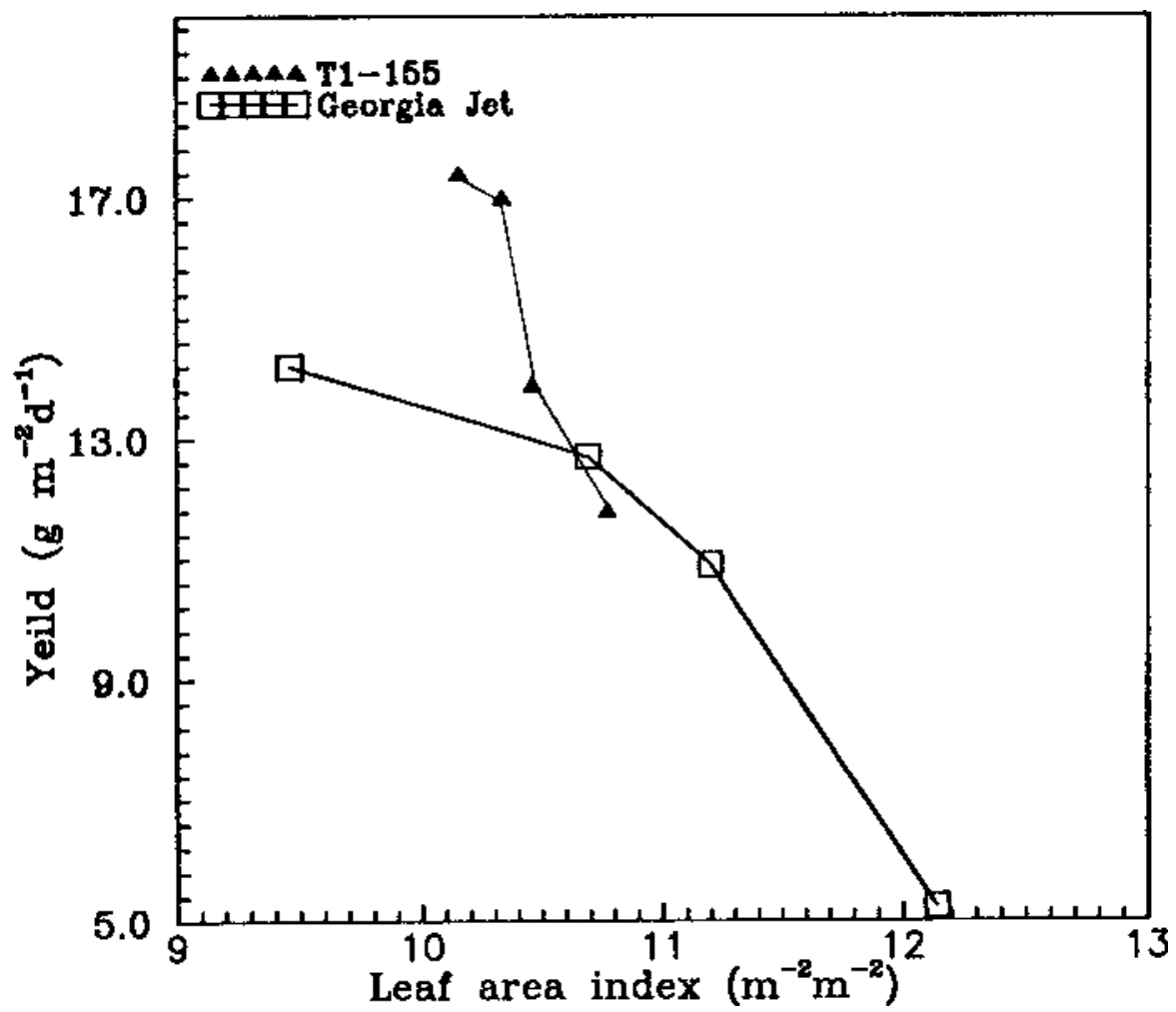

Fig. 3. Relationship between yield and leaf area index of TI-155 and 'Georgia Jet' sweetpotatoes in response to daily photosynthetic photon flux (PPF). 

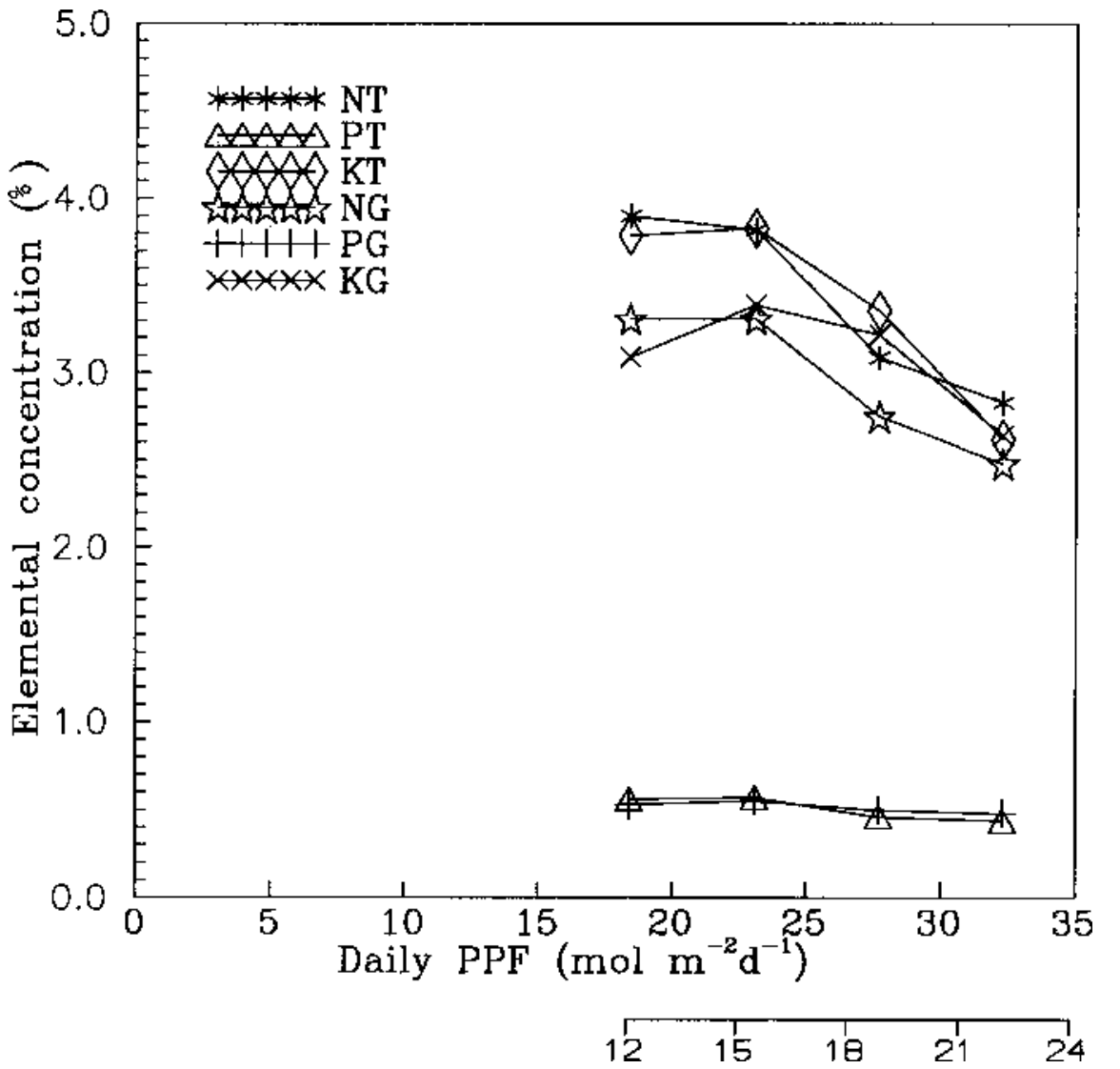

Fig. 4. Elemental concentration (dry-mass basis) of TI-155 and 'Georgia Jet' sweetpotatoes in response to daily photosynthetic photon flux (PPF). (Concentration of N, P, and K for TI-155 = NT, PT, and KT, respectively; for 'Georgia Jet' = NG, PG, and KG, respectively.)

levels in TI-155 by the longer light periods because of reduced sink capacity, causing feedback inhibition of photosynthesis and leaf damage (Clough et al., 1981; Ehret and Jolliffe, 1985; Sasek et al., 1985). Also, Cushman and Tibbitts (1994) recently suggested that ethylene may have a role in the development of constant-light injury symptoms in plants.

Increasing the light period from 12 to $21 \mathrm{~h}$ decreased stomatal conductance of both genotypes (Fig. 2). The relationship between leaf area index (LAI) and storage root yield showed that final yield for both cultivars declined as LAI increased (Fig. $3 \mathrm{a}$ and b).

Leaf analyses data showed that light period significantly influenced $\mathrm{N}$ and $\mathrm{K}$ concentrations but had no consistent effect on $\mathrm{P}$ levels (Fig. 4). Generally, leaf N and K decreased with increased daily PPF and varied, depending on genotype, particularly for N. Concentrations of $\mathrm{P}, \mathrm{Mn}, \mathrm{Ca}, \mathrm{Mg}, \mathrm{Fe}, \mathrm{B}, \mathrm{Cu}$, and $\mathrm{Zn}$ (data not shown) were not significantly influenced by daily PPF or genotype. Generally, the values for elemental concentrations were within the sufficiency ranges associated with optimum sweetpotato growth and production (Jones et al., 1991).

The light period treatments were applied with a constant PPF, hence they reflected differences in total irradiance. Although this result differs from those of studies that used dim daylength extension, which tests true photoperiod response, the constant PPF is pertinent for CELSS testing where the optimal combination of daylength with maximum lighting is needed.

Our results showed that sweetpotato growth, yield, and physiological responses in NFT varied with light period and the genotypes used. The results further indicate that TI155 may be more sensitive to longer light periods than 'Georgia Jet', which appeared to have a higher light threshold.

\section{Literature Cited}

Bhagsari, A.S. and D.A. Ashley. 1990. Relationship of photosynthesis and harvest index to sweetpotato yield. J. Amer. Soc. Hort. Sci. 115:288-293.

Bonsi, C.K., W.A. Hill, D.G. Mortley, P.A. Loretan, C.E. Morris, and E.R. Carlisle. 1993. Growing sweetpotatoes for space missions using NFT, $\mathrm{p}$. 110-118. In: W.A. Hill, C.K. Bonsi, and P.A. Loretan (eds.). Sweetpotato technology for the 21st century. Tuskegee Univ., Tuskegee, Ala.

Bonsi, C.K., P.A. Loretan, W.A. Hill, and D.G. Mortley. 1992. Response of sweetpotatoes to continuous light. HortScience 27:471.

Bouwkamp, J.C. 1985. Sweetpotato products: A natural resource for the tropics. CRC Press, Boca Raton, Fla.

Clough, J.M., M.M. Peet, and P. Kramer. 1981. Effects of high atmospheric $\mathrm{CO}_{2}$ and sink size on rates of photosynthesis of soybean cultivar. Plant Physiol. 67:1007-1010.

Cooper, A.J. 1974a. Soil? Who needs it? Part 1. Amer. Veg. Grower 22(8):18, 20.

Cooper, A.J. 1974b. Soil? Who needs it? Part 2. Amer. Veg. Grower 22(9):13, 64.

Cushman, K.E. and T.W. Tibbitts. 1994. The role of ethylene in the development of constant light injury of potato. HortScience 29:446.

Ehret, D.L. and P.A. Jolliffe. 1985. Leaf injury to bean plants grown in carbon dioxide enriched atmospheres. Can. J. Bot. 63:2015-2020.

Hill, W.A., P.A. Loretan, C.K. Bonsi, C.E. Morris, J.Y. Lu, R.D. Pace, and C.R. Ogbuehi. 1989. Utilization of sweetpotatoes in controlled ecological lifesupport systems (CELSS). Adv. Space Res. 9:29-41.

Hoagland, D.R. and D.I Arnon. 1950. The waterculture method for growing plants without soil. Calif. Agr. Expt. Sta. Circ. 347. Univ. of California, Berkeley.

Hue, N. and C.E. Evans. 1986. Procedures used by the Auburn University Soil Testing Laboratory. Auburn Univ. Agr. Expt. Sta. Ser. 16 (rev.)

Jones, J.B., Jr., B. Wolf, and H.A. Mills. 1991. Plant analysis handbook. A practical sampling, preparation, analysis and interpretation guide. MicroMacro Publishing, Athens, Ga.

Kim, Y.C. 1957. Studies on the photoperiodical control for tuber formation in sweetpotato. Korean J. Bot. 2:35-42.

Loretan, P.A., C.K. Bonsi, W.A. Hill, C.R. Ogbuehi, D.G. Mortley, J.Y. Lu, C.E. Morris, and R.D. Pace. 1989. Sweetpotato growth parameters, yield components and nutritive value for CELSS applications. J. AeroSpace 98:1090-1094.

McDavid, C.R. and S. Alamu. 1980. Effect of day length on the growth and development of whole plants and rooted leaves of sweetpotato (Ipomoea batatas). Trop. Agr. (Trinidad) 57:113-119.

Morris, C.E., P.A. Loretan, C.E. Bonsi, and W.A. Hill. 1989. Movable root contact pressure plate assembly for hydroponic system. U.S. Patent 4860490. Date issued 29 Aug. 1989.

Mortley, D.G., P.A. Loretan, C.K. Bonsi, W.A. Hill, and C.E. Morris. 1991a. Plant spacing influences yield and linear growth rate of sweetpotatoes grown hydroponically. HortScience 26:1274-1275.

Mortley, D.G., C.K. Bonsi, P.A. Loretan, C.E. Morris, W.A. Hill, and C.R. Ogbuehi. 1991b. Evaluation of sweetpotato genotypes for adaptability to hydroponic systems. Crop Sci. 31:845847.

Mortley, D.G., C.K. Bonsi, W.A. Hill, P.A. Loretan, and C.E. Morris. 1993. Irradiance and nitrogen to potassium ratio influences sweetpotato yield in nutrient film technique. Crop Sci. 33:782-784.

Porter, W.C. 1979. Sweetpotato growth as affected by photoperiod. HortScience 14:124.

SAS Institute. 1985. SAS user's guide: Statistics, Version 5 ed. SAS Inst., Cary, N.C.

Sasek, T.W., E.H. DeLucia, and B.R. Strain. 1985. Reversibility of photosynthetic inhibition in cotton after long-term exposure to elevated $\mathrm{CO}_{2}$ concentration. Plant Physiol. 78:721-725.

Tibbitts, T.W. and W. Cao. 1994. Solid matrix and liquid culture procedures for growth of potatoes. Adv. Space Res. 14:427-443. 